\title{
Desiccation tolerance of cambuci seeds
}

\author{
Marcelo Brossi Santoro ${ }^{*}\left(\mathbb{D}\right.$, Bruna do Amaral Brogio' $^{(0)}$, Victor Augusto Forti ${ }^{(D)}$,

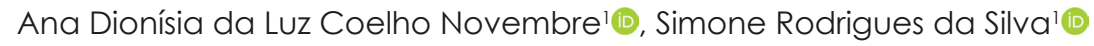

\author{
'University of São Paulo, Piracicaba, Brazil \\ ${ }^{2}$ Federal University of São Carlos, Araras, Brazil \\ *Corresponding author, e-mail: marcelo.santoro@usp.br
}

\begin{abstract}
This work aimed to evaluate the interference of seed desiccation on the occurrence of root protrusion and the formation of normal cambuci seedlings. Seeds were obtained from mature fruits collected from adult plants and submitted to oven drying with forced air circulation at $30 \pm 2^{\circ} \mathrm{C}$ in order to obtain different water contents. The seeds were then submitted to the germination test in a completely randomized design at $25^{\circ} \mathrm{C}$ and 12 hours photoperiod, and were weekly evaluated for a period of 90 days, regarding the number of seeds with root protrusion, the number of dead seeds and normal seedlings. At the end the germination speed index (GSI) the mean germination time (MGT) and the average speed of germination (ASG) were calculated. Any of these variables were significantly affected until the water content decreased to $14.9 \%$, whereas at $9.1 \%$ and $6.6 \%$ water contents, there was a significant reduction of root protrusion and GSI, and a higher percentage of dead seeds. Cambuci seeds tolerate desiccation down to $15 \%$ water content without losing viability.
\end{abstract}

Keywords: Myrtaceae, Campomanesia phaea, moisture content and viability

\section{Introduction}

The Myrtaceae family is composed by approximately 6.000 species classified into 145 genera (The Plant List, 2013) which are spread on nearly all the continents, except on the Antarctica. The main diversity centers are located in Australia, Southeast Asia and South America (Wilson et al., 2005).

In South America all the representative species belong to the Myrtoideae subfamily, and in Brazil they are classified into the Myrteae tribe (Wilson et al., 2005). With over a hundred species widely distributed throughout the Brazilian territory, the Myrtaceae family has vast genetic patrimony and potential for economic exploitation (Lattuada et al., 2010).

Some Myrtceae tree species such as the cambuci (Campomanesia phaea O. Berg.), feijoa (Acca sellowiana (O. Berg) Burret.), guabiroba (Campomanesia xanthocarpa O. Berg.), grumixama (Eugenia brasiliensis
Lam.), cereja-do-Rio-Grande-cherry (Eugenia involucrata DC.) and uvaia (Eugenia pyriformis Camb.) have been highlighted thanks to the organoleptic properties of their fruits, their potential for agricultural exploitation and their use for recovering degraded areas (Delgado \& Barbedo, 2007; Lattuada et al., 2010; Zillo et al., 2013; Gomes et al., 2015; Tokairin et al., 2018a).

Cambuci tree is native of the Atlantic forest and it is found in states of the Southeast region of Brazil (CNCFLORA, 2012), being endemic to São Paulo state, where it is, distributed from the Serra do Mar until the Paulista Plateau (Lorenzi, 2009). The plant reaches a height of 8 to 16 meters and has a trunk diameter of 20 to $30 \mathrm{~cm}$, with a scaly bark, as also found in other species of the Myrtaceae family (Andrade et al., 2011). The fruits may be sold and consumed in natura, despite of their low carbohydrate content and high acidity, or may be processed in juices, liquors and jellies, keeping their 
organoleptic properties and adequate levels of ascorbic acid, minerals or dietary fiber (Instituto Auá, 2017; Tokairin et al., 2018b).

Increasing demand for cambuci fruits in the domestic markets requires an enhanced plant production process, which is currently based on seeds, and only a few studies are available on cambuci seed germination and storage capacity (Rego et al., 2009; Gomes et al., 2016).

Seeds from several Myrtaceae species, such as jambo-do-mato (Calyptranthes lucida Mart.), pitangado-mato (Eugenia handroana D. Legrand) and camucamu (Myrciaria dubia (H.B.K.) McVaugh) have shown to be recalcitrant and sensitive to moisture loss during desiccation and storage (Yuyama et al., 2011; Scalon et al., 2012), especially those seeds with high moisture content at the physiological ripening, as occurs in many species of the Eugenia genus (Delgado \& Barbedo, 2007; Gomes et al., 2016). For the Campomanesia genus, diverging results are available in studies on seed tolerance to desiccation (Maluf \& Pisciottano-Ereio, 2005; Melchior et al., 2006).

In this context, the objective of this study was to evaluate the interference of seed desiccation on radicle protrusion and development of normal cambuci seedlings.

\section{Material and Methods}

The study was carried out in the Laboratory of Seed Analysis of the Department of Plant Production at the Luiz de Queiroz College of Agriculture of the University of São Paulo (USP) in Piracicaba, São Paulo, Brazil, using seeds of cambuci fruits randomly picked from distinct plants on a commercial grove located in Natividade da

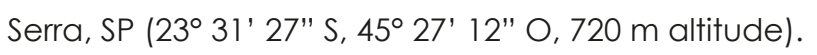

The seeds were extracted from ripe fruits by using a sieve, sand and running water. In order to completely remove the fruit pulp from the seeds, it was first disposed in the sieve with sand and rubbed together for removing the seeds. The seeds were then washed in tap water and placed on tissue paper for drying out the excess water. The mass of seeds was homogenized and a sample was taken for determination of initial moisture content in an oven at $105 \pm 3^{\circ} \mathrm{C}$ for 24 hours (Brasil, 2009), and the rest of the seeds was disposed in a waterproof plastic bag and stored at $20^{\circ} \mathrm{C}$ for 2 days.

The extracted seeds were dried in oven with forced air circulation at $30 \pm 2^{\circ} \mathrm{C}$. The seed moisture depletion was monitored through two previously weighed samples, which were dried together with the rest of the seeds. As these samples achieved the desired moisture contents,
150 seeds were removed from the oven, disposed in a transparent water-proof plastic bag, tagged and cold stored at $20^{\circ} \mathrm{C}$. The treatments consisted in the different seed moisture contents measured, on a wet weight basis: T1: control (52.1\%); T2 (46.2\%), T3 (35.9\%), T4 (32.8\%), T5 (30.2\%), T6 (23.4\%), T7 (19.8\%), T8 (14.9\%), T9 (9.1\%) and $\mathrm{T} 10$ (6.6\%).

Once all treatments were obtained the seeds were submitted to a germination test and disposed in a completely randomized design, with 10 treatments and, 6 repetitions of 25 seeds per treatment. The test was carried out on three germitest paper rolls moistened with a water volume corresponding to 2.3 times the weight of the paper roll, and were vertically disposed inside a Mangelsdorf (MA 401) germination chamber, at $25^{\circ} \mathrm{C}$ and under a constant 12-hour photoperiod (Gomes et al., 2016).

Each treatment was weekly evaluated along a 90-day period regarding the number of seeds showing radicle protrusion (RP), the number of normal-type plants (NP) and the number of dead seeds (DS). At the end of the evaluations, the germination speed index (GSI) was calculated for the whole experimental period, as described by Maguire (1962): $\mathrm{GSI}=\mathrm{G}_{1} / \mathrm{N}_{1}+\mathrm{G}_{2} / \mathrm{N}_{2}+\ldots+$ $G_{n} / N_{n}$, where $G_{1}, G_{2}, G_{n}$ are the number of normal-type plants in each evaluation and $N_{1}, N_{2}, N_{n}$ are the number of days after installing the trial.

In the same way, as described by Borghetti \& Ferreira (2004), the mean germination time (MGT), MGT $=\Sigma\left(n_{i}, t_{i}\right) / \Sigma n_{i}$, where $n_{i}$ is number of normal-type plants in each evaluation and $t_{i}$ is the time between the i-th evaluation and the beginning of the trial, and the average speed of germination (ASG), ASG = 1 / MGT, were also calculated.

Comparisons among means by the Tukey's test $(p<0.01$ ) and regression analyses were performed. Additionally, a Pearson's correlation analysis between the residues of RP on day 30 and NP on day 90 after installation was also performed. All statistical analyses were performed using SAS ${ }^{\circledR}$ statistical software (SAS Institute, Inc., Cary, NC, USA) and all graphics designed using Sigma Plot Version 12.0 (Systat Software, San Jose, CA).

\section{Results and Discussion}

The average initial seed moisture content was $52.1 \%$ (Figure 1), similar to the values reported by Maluf \& Pisciottano-Ereio (2005) and by Gomes et al., (2016) of $48.7 \%$ and $54.0 \%$ in seeds of C. phaea and C. xanthocarpa (guabiroba), respectively. Conversely, the seeds of other species of the same genus, such as C. guazumifolia 
(sete-capotes) had either lower initial moisture contents, below 10\% (Santos et al., 2004), or intermediate moisture contents, of $35 \%$ in seeds of C. pubescens (gabiroba de arbusto) (Dousseau et al., 2011).

High initial seed moisture contents are directly related with the sensibility to desiccation (Scalon et al., 2012). The seeds of several species of the Eugenia genus, such as E. brasiliensis, E. uniflora and E. involucrata, with initial moisture contents between 47 to $65 \%$, were classified as recalcitrant, because they lost viability at moisture contents between 45-50\% (Delgado \& Barbedo, 2007).

A slow and gradual reduction of moisture content was observed along the drying process of cambuci seeds (Figure 1), as it was also reported for seeds of C. phaea, C. pubescens and E. pyriformis (Maluf \& Pisciottano-Ereio, 2005; Dousseau et al., 2011 ; Scalon et al., 2012).

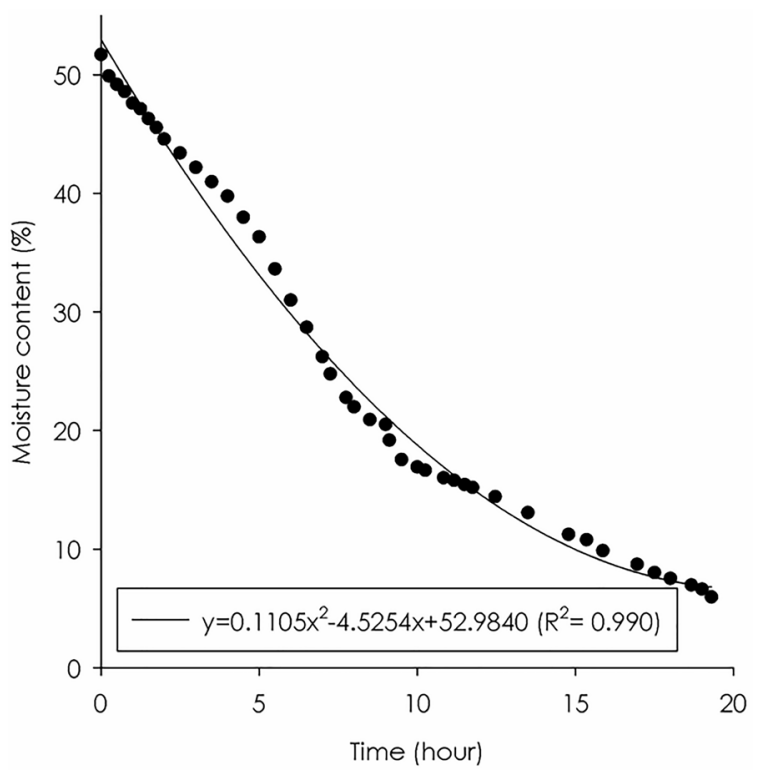

Figure 1. Moisture content of cambuci (Campomanesia phaea) seeds (wet weight basis) during seed drying in oven with forced air circulation at $30 \pm 2^{\circ} \mathrm{C}$. Piracicaba, SP, Brazil, 2018.

Seed drying process may cause viability loss, therefore, it is important to determine the security moisture level that might be achieved before this loss will occur, the critical moisture level at which loss of viability occurs, and the lethal moisture level at which the seeds do not germinate (Hong \& Ellis, 1996).

Significant differences were observed $(p<0.01)$ between the evaluated seed moisture levels for all the assessed variables: radicle protrusion, number of normaltype plants, number of dead seeds and GSI. After 90 DAI the treatments with lower seed water contents T9 (9.1\%) and $\mathrm{T} 10(6.6 \%)$ achieved significantly lower percentages of RP, NP, DS and lower GSI than the other treatments
(Table 1).

These results indicate that the critical moisture content for cambuci seeds is $14.9 \%$, even though some authors have reported seed germination with moisture contents of only 3\% (Maluf \& Pisciottano-Ereio, 2005). And thus, considering only the moisture content, the cambuci seeds could be classified as orthodox. Other authors observed a reduction on the physiological potential in seeds of $C$. pubescens and $E$. pyriformis when desiccation achieved $30 \%$ moisture content, and classified those seeds as recalcitrant (Dousseau et al., 2011 ; Scalon et al., 2012).

Significant differences between the treatments were also observed for the number of dead seeds, indicating a larger mortality at low seed moisture content. Lowest moisture values in T9 (9.1\%) and T10 (6.6\%) treatments resulted in mean seed mortality percentages of 42.67 and $62.00 \%$, respectively (Table 1). Seed tolerance to desiccation depends on a number of protection systems operating at each moisture depletion level. It also depends on the type of water removed at each step, and on the presence or absence of such protection systems (Delgado \& Barbedo, 2007). In this trial, the lower evaluated moisture contents could have exceeded the seed resistance to drought, causing a high seed mortality rate. Nonetheless, no lethal seed moisture contents were identified for $C$. phaea seeds, since germination occurred at all the evaluated seed moisture levels.

As seed moisture content decreased, GSI also reduced (Table 1). Melchior et al. (2006) reported a similar performance in seeds of C. adamantium (gabiroba), in which a reduction of seed moisture content resulted in lower germination and GSI.

The regression curve indicated a progressive increase of GSI, until a maximum of 0.3007 observed at $34.31 \%$ moisture content, which corresponds to a 4.8-hour drying time, similar to the result reported by Dousseau et al. (2011) in C. pubescens. However, this increase in GSI was not enough guarantee significant differences among treatments $\mathrm{Tl}$ through T8 (Table 1).

When it comes to the mean time of germination, on average, the cambuci seeds took 71 days to completely form a normal-type plant. On the other hand, treatments with lower moisture contents, T9 (9.1\%) and T10 (6.6\%), needed more time, 76 and 78 days, respectively. Moreover, the same treatments presented the lowest values of average speed of germination, reinforcing the fact that $14.9 \%$ is the critical moisture content for cambuci seeds (data not shown). 
Table 1. Percentages of radicle protrusion (RP), normal-type plants (NP), dead seeds (DS) and germination speed index (GSI) of Campomanesia phaea seeds submitted to different desiccation levels 90 days after installing the trial. Piracicaba, SP, Brazil, 2018.

\begin{tabular}{|c|c|c|c|c|c|}
\hline \multirow{2}{*}{$\begin{array}{c}\text { Moisture content } \\
(\%)\end{array}$} & \multirow{2}{*}{$\begin{array}{l}\text { Drying time } \\
\text { (hours) }\end{array}$} & $\mathrm{RP}^{*}$ & $N P^{*}$ & $\mathrm{DS}^{*}$ & \multirow{2}{*}{ GSI } \\
\hline & & & $\%$ & & \\
\hline $\mathrm{Tl}(52.1)$ & 0 & $84.00 \mathrm{a}$ & $68.80 \mathrm{a}$ & $14.00 \mathrm{a}$ & $0.25 a b$ \\
\hline T2 (46.2) & 1.75 & $80.00 \mathrm{a}$ & $60.67 \mathrm{a}$ & $18.68 \mathrm{a}$ & $0.22 a b$ \\
\hline T3 (35.9) & 4.00 & $86.00 \mathrm{a}$ & $76.67 \mathrm{a}$ & $13.33 \mathrm{a}$ & $0.29 \mathrm{ab}$ \\
\hline T4 (32.8) & 5.50 & $90.00 \mathrm{a}$ & 75.33 a & $8.00 \mathrm{a}$ & $0.27 a b$ \\
\hline T5 (30.2) & 6.00 & $90.67 \mathrm{a}$ & $78.00 \mathrm{a}$ & $9.33 \mathrm{a}$ & $0.28 a b$ \\
\hline T6 (23.4) & 7.25 & $89.33 a$ & $66.67 \mathrm{a}$ & $7.33 \mathrm{a}$ & $0.27 \mathrm{ab}$ \\
\hline T7 (19.8) & 8.50 & $96.67 \mathrm{a}$ & $84.00 \mathrm{a}$ & $3.33 \mathrm{a}$ & $0.30 a$ \\
\hline T8 (14.9) & 11.75 & $80.00 \mathrm{a}$ & $57.33 \mathrm{ab}$ & $16.00 \mathrm{a}$ & $0.20 \mathrm{bc}$ \\
\hline T9 (9.1) & 15.86 & $52.67 \mathrm{~b}$ & $31,33 \mathrm{bc}$ & $42.67 \mathrm{~b}$ & $0.11 \mathrm{~cd}$ \\
\hline $\mathrm{T} 10$ (6.6) & 19.30 & $34.67 \mathrm{~b}$ & $11.33 \mathrm{c}$ & $62.00 \mathrm{C}$ & $0.03 d$ \\
\hline P-value & - & $<0.0001$ & $<0.0001$ & $<0.0001$ & $<0.0001$ \\
\hline $\mathrm{F}$ & - & 35.03 & 22.52 & 31.04 & 25.41 \\
\hline CV (\%) & - & 10.27 & 19.39 & 41.70 & 18.58 \\
\hline
\end{tabular}

Despite that Pearson's correlation test on the residues was not significant and did not indicated any relationship between the number of normal-type plants after 90 days and the number of seeds showing radicle protrusion after 30 days from installing the trial (data not shown). The number of normal-type plants at the end of the experiment might have been predicted by the observed number of seeds showing radicle protrusion on day 30 (Figure 2), a fact that may reduce the duration of seed germination tests in this species by over 60 days, considering its low germination capacity.

As the species domestication still is on its first steps, our finds begin to clarify the behavior of cambuci seeds under different moisture contents.

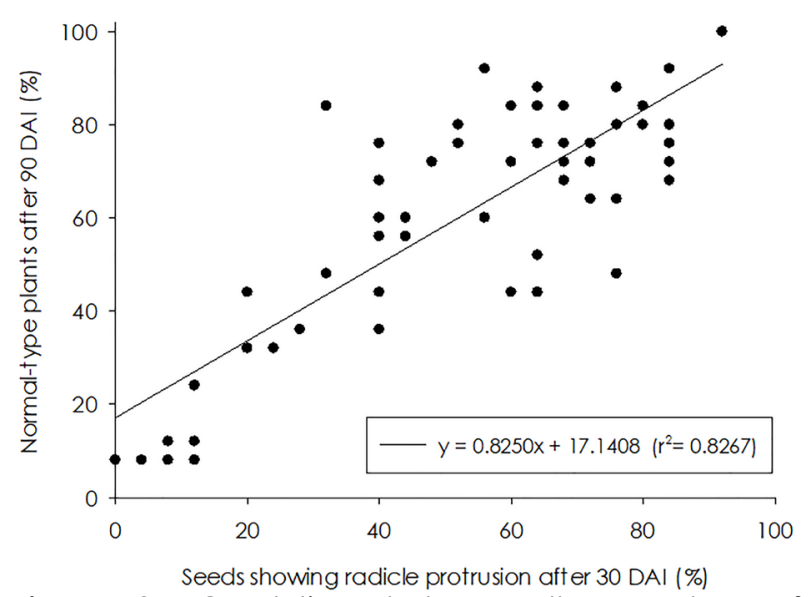

Figure 2. Correlation between the number of Campomanesia phaea seeds showing radicle protrusion after 30 days and the number of normal-type plants observed 90 days after installing (DAI) the trial. Piracicaba, SP, Brazil, 2018.

\section{Conclusions}

The seeds of $C$. phaea tolerate desiccation and preserve their viability until $15 \%$ moisture content regardless of the variable utilized for quantifying seed germination.

\section{Acknowledgements}

The authors acknowledge the M.Sc. scholarship awarded by CAPES (Process ID Number 1732467) and the scientific productivity grant awarded by the "National Council for Scientific and Technological Development CNPq".

\section{References}

Andrade, B.A.G.F., Fonseca, P.Y.G., Lemos, F. (Org.). 2011. Cambuci - o fruto, o bairro, a rota: história, cultura, sustentabilidade e gastronomia. Ourivesaria da Palavra, São Paulo, Brazil. 176 p.

Borghetti, F., Ferreira, A.G. 2004. Interpretação de resultados de germinação. In: Ferreira, A.G., Borghetti, F. (eds.) Germinação: do básico ao aplicado. Artmed, Porto Alegre, Brazil. p. 209-222

Brasil, Ministério da Agricultura, Pecuária e Abastecimento. 2009. Regras para análise de sementes. Ministério da Agricultura, Pecuária e Abastecimento, Secretaria de Defesa Agropecuária, Brasília, Brazil. 399 p.

CNCFLORA. Centro Nacional de Conservação da Flora. Campomanesia phaea in Lista Vermelha da flora brasileira v. 2012.2. 2012. http://cncflora.jbrj.gov.br/ portal/pt-br/profile/Campomanesia phaea<Access on 10 Apr. 2019>

Delgado, L.F., Barbedo, C.J. 2007. Tolerância à dessecação de sementes de espécies de Eugenia. Pesquisa Agropecuária Brasileira 42: 265-272.

Dousseau, S., Alvarengam A.A., Guimarães, R.M., Lara, T.S., Custódio, T.N., Chaves, I.S. 2011. Ecofisiologia da germinação de sementes de Campomanesia pubescens. Ciência Rural 41: 1362-1368.

Gomes, J.P., Oliveira, L.M., Ferreira, P.I., Batista, F. 2016. Substratos e temperaturas para teste de germinação em sementes de Myrtaceae. Ciência Florestal 26: 285-293. 
Gomes, J.P., Oliveira, L.M., França, C.S.S, Dacoregio, H.M., Bortoluzzi, R.L.C. 2015. Caracterização morfológica de plântulas durante a germinação de sementes de Psidium cattleianum e Acca sellowiana (MYRTACEAE). Ciência Florestal 25: 1035-1042.

Hong, T.D., Ellis, R.H. 1996. A protocol to determine seed storage behaviour. International Plant Genetic Resources Institute, Rome, Italy. 55 p. (Technical Bulletin, 1).

Instituto Auá. Empreendimentos socioambiental. Rota do Cambuci. 2017. http://institutoaua.org.br/ empreendimentos/rota-do-cambuci/<Access on $1^{\text {st }}$ May 2020>

Lattuada, D.S., Souza, P.V.D., Gonzatto, M.P. 2010. Enxertia herbácea em Myrtaceae nativas do Rio Grande do Sul. Revista Brasileira de Fruticultura 32: 1285-1288.

Lorenzi, H. 2009. Árvores Brasileiras: manual de identificação e cultivo de plantas arbóreas nativas do Brasil. 3.ed. Nova Odessa: Instituto Plantarum, Brazil. 384 p.

Maguire, J.D. 1962. Speed of germination-aid in selection evaluation for seedling emergence and vigour. Crop Science 2: 176-177.

Maluf, A.M., Pisciottano-Ereio, W.A. 2005. Secagem e armazenamento de sementes de cambuci. Pesquisa Agropecuária Brasileira 40: 707-714.

Melchior, S.J., Custodio, C.C., Marques, T.A., Machado Neto, N.B. 2006. Colheita e armazenamento de sementes de gabiroba (Campomanesia adamantium Camb. - Myrtaceae) e implicações na germinação. Revista Brasileira de Sementes 28: 141-150.

Rego, S.S., Nogueira, A.C., Kuniyoshi Y.S., Santos, A.F. 2009. Germinação de sementes de Blepharocalyx salicifolius (H.B.K.) Berg. em diferentes substratos e condições de temperatura, luz e umidade. Revista Brasileira de Sementes 31: 212-220.

Santos, C.M.R., Ferreira, A.G., Áquila, M.E.A. 2004. Características de frutos e germinação de sementes de seis espécies de Myrtaceae nativas do Rio Grande do Sul. Ciência Florestal 14: 13-20.

Scalon, S.P.Q., Neves, E.M.S., Maseto, T.E., Pereira, Z.V. 2012. Sensibilidade à dessecação e ao armazenamento de sementes de Eugenia pyriformis Cambess. (Uvaia). Revista Brasileira de Fruticultura 34: 269-276.

THE PLANT LIST. A working list of all plant species. Version 1.1. 2013. http://Www.theplantlist.org/ <Access on 30 Aug. 2018>

Tokairin, T.O., Bremer Neto, H., Jacomino, A.P. 2018 a. Cambuci - Campomanesia phaea (O.Berg) Landrum. In: Rodrigues, S., Silva, E.O., Brito, E.S. (eds.) Exotic fruits: reference guide. Elsevier, London, United Kingdom. p. 91 96.

Tokairin, T.O., Silva, A.P.G., Spricigo, P.C., Alencar, S.M., Jacomino, A.P. 2018b. Cambuci: a native fruit from the Brazilian Atlantic forest showed nutraceutical characteristics. Revista Brasileira de Fruticultura 40: 1-8.

Wilson, P.G., O'Brien, M.M., Heslewood, M.M., Quinn, C.J. 2005. Relationships within Myrtaceae sensu lato based on a matK phylogeny. Plant Systematics and evolution 251: 3-19.

Yuyama, K., Mendes, N.B., Valente, J.P. 2011 . Longevidade de sementes de camu-camu submetidas a diferentes ambientes e formas de conservação. Revista Brasileira de Fruticultura 33: 601-607.

Zillo, R.R., Silva, P.P.M., Zanata, S., Carmo, L.F., Spoto, M.H.F. 2013. Qualidade físico-química da fruta in natura e da polpa de uvaia congelada. Revista Brasileira de Produtos Agroindustriais 15: 293-298.

Conflict of Interest Statement: The authors declare that the research was conducted in the absence of any commercial or financial relationships that could be construed as a potential conflict of interest.

All the contents of this journal, except where otherwise noted, is licensed under a Creative Commons Attribution License attribuition-type BY. 